\title{
PEMODELAN DESAIN SISTEM INFORMASI PENGOLAHAN DATA PRODUK DEKRANASDA PROVINSI KALIMANTAN TENGAH MENGGUNAKAN UML
}

\author{
Lili Rusdiana \\ Sistem Informasi, STMIK Palangkaraya \\ e-mail: sohib.sahabat@gmail.com
}

\begin{abstract}
ABSTRAK
Pemodelan dilakukan untuk membantu memecahkan permasalahan mengenai pengolahan data produk kerajinan tangan pada DEKRANASDA (Dewan Kerajinan Nasional Tingkat Daerah) Provinsi Kalimantan Tengah karena adanya keterbatasan data produk yang didapat dari alur sistem yang berjalan saat ini sehingga diperlukan pengolahan data untuk mempermudah melakukan pengolahan data produk. Penulisan ini bertujuan untuk memahami permasalahan dan mengkomunikasikan dengan pengguna yang terlibat pada sistem serta mengidentifikasi kebutuhan informasi data produk dengan menggunakan pemodelan UML (Unified Modelling Language). Terdapat 3 diagram yang digunakan dalam pemodelan sistem menggunakan UML pada penulisan ini yaitu Use Case Diagram, Class Diagram, dan Sequence Diagram. Hasil dari pemodelan yang dilakukan yakni dapat menggambarkan cara atau alur penggunaan sistem dari pengelola yang menjadi aktor, memperlihatkan cara aliran bisnis mengalir dalam suatu sistem serta dapat memberikan gambaran sistem secara statis yang memperlihatkan relasi atau hubungan antarkelas yang saling berkaitan mengenai sistem informasi pengolahan data produk kerajinan pada DEKRANASDA Provinsi Kalimantan Tengah.
\end{abstract}

Kata Kunci: DEKRANASDA, Kalimantan Tengah, Perancangan, UML

\begin{abstract}
Modelling is conducted to solve the problems regarding data processing of handicrafts products on DEKRANASDA (Regional Crafts Board)of Central Kalimantan due to limitations of the data obtained from the product flow of the current system so that data processingis required to simplify data processing products. This research aims to understand the problems, communicate with the users involved in the system, and identify the information needs of product data modeling using UML (Unified Modeling Language). In this research, there were 3 diagrams used in the system modeling using UML that is Use Case Diagram, Class Diagram, and Sequence Diagram. The results of the modelling described how to use the system or the groove of the manager who became adoer, showed how the business flows in a system, and gave a static picture of a system showing the relationship between the interrelated classes in information system of handicraft products data processing on DEKRANASDA of Central Kalimantan.
\end{abstract}

Keywords: DEKRANASDA, Central Borneo, Design, UML

\section{PENDAHULUAN}

$\mathrm{P}$ erancangan sistem sangat diperlukan dalam pembangunan sebuah sistem informasi karena perancangan termasuk ke dalam salah satu tahapan yang digunakan agar sistem yang dibangun dapat berjalan sesuai dengan perencanaan dan dapat memiliki manfaat bagi organisasi. Perancangan yang dilakukan merupakan hasil dari analisis terhadap permasalahan yang terjadi dalam tahapan pembangunan sistem. Salah satu tool perancangan yaitu Unified Modelling Language (UML) sebagai notasi yang dapat digunakan dalam merancang sebuah sistem informasi agar dapat memudahkan dalam memahami konsep, aktivitas, dan implementasi perancangan [1]. Perancangan dapat meminimalkan kesalahan dalam membangun dan mengembangkan sistem informasi.

Penelitian ini mengembangkan penelitian sebelumnya yang merancang sistem informasi menggunakan Entity Relationship Diagram (ERD) dan Data Flow Diagram (DFD) terkait produk DEKRANASDA (Dewan Kerajinan Nasional Tingkat Daerah). Tujuan penelitian adalah untuk mengetahui alur sistem terkait basis data pada penelitian mengenai sistem informasi DEKRANASDA Provinsi Kalimantan Tengah berbasis Web agar meminimalkan waktu proses pengenalan produk karena terhambatnya pengenalan produk yang ada pada showroom DEKRANASDA yang dimiliki masing-masing Kabupaten dan Kota kepada masyarakat luas yang hanya melalui pameran. Hal ini menyebabkan tidak semua kalangan masyarakat mengetahui dan mengenal produk yang ada pada Provinsi Kalimantan Tengah [2].

DEKRANASDA Provinsi Kalimantan Tengah merupakan salah satu organisasi yang berada di bawah naungan Dinas Perindustrian dan Perdagangan. Dinas Perindustrian dan Perdagangan mendukung kelancaran kegiatan DEKRANAS tingkat daerah yang berfungsi dalam membantu dan sebagai mitra pemerintah dalam membina dan mengembangkan produk kerajinan daerah. 
Beberapa produk yang terdapat pada showroom merupakan contoh produk-produk dari beberapa daerah yang meliputi Kota dan Kabupaten. Akan tetapi, produk yang berada pada showroom tersebut tidak memiliki data yang lengkap seperti nama barang, asal daerah, data pengrajin, dan lainnya. Sehingga hal tersebut kurang memberikan informasi produk terhadap pengunjung yang berkunjung pada showroom untuk melihat produk-produk pada showroom. Beberapa produk dipajang dan hanya beberapa produk saja yang memiliki data tetapi masih kurang lengkap dan masih banyak lagi produk yang tidak memiliki data yang lengkap baik pada produk yang dipajang maupun data produk yang masuk pada showroom.

Pengembangan perancangan yang dilakukan terkait pengolahan data produk pada showroom DEKRANASDA Provinsi Kalimantan Tengah yang berada di Kota Palangkaraya dan mengembangkan perancangan menggunakan pemodelan UML yang bertujuan untuk memahami permasalahan dan mengkomunikasikan dengan pengguna yang terlibat dengan sistem serta mengidentifikasi kebutuhan informasi data produk yang terdapat pada DEKRANASDA Provinsi Kalimantan Tengah dengan menggunakan pemodelan UML.

Perancangan menggunakan UML juga dilakukan dengan melibatkan beberapa diagram yaitu class diagram, object diagram dan activity diagram dalam kasus keuangan [3]. Penelitian terkait ontology juga dilakukan dengan menggunakan class diagram, object diagram dan statechart diagram [4].

Use case diagram pada UML digunakan untuk analisis dan perancangan sistem informasi card management sebagai penentu aktor yang berintegrasi dengan sistem agar sistem dapat meminimalkan kesalahan pendataan, pencetakan, maupun pendistribusian sehingga dapat meningkatkan service level nasabah [5]. UML digunakan sebagai sarana untuk memvisualisasikan, menspesifikasikan, membangun, dan mendokumentasikan hasil dari sebuah sistem dengan menggunakan 3 diagram yang dipilih yaitu use case diagram yang dapat menunjukkan adanya hubungan interaksi dari aktor dan use cases dalam suatu sistem. Sequence diagram yang digunakan dalam menganalisis untuk memperlihatkan cara aliran bisnis mengalir pada suatu sistem dan penggunaan class diagram yang dapat memberikan gambaran sistem secara statis untuk memperlihatkan relasi atau hubungan antarkelas yang saling berkaitan. Perancangan dilakukan setelah didapat hasil dari analisis sebagai dasar untuk merencanakan, mengumpulkan, dan mengorganisasikan serta mengendalikan data dan informasi yang telah digabung.

Penelitian yang menggunakan UML juga dilakukan dalam hal pengelolaan data untuk perancangan Website EGov pada studi kasus kabupaten pamekasan. Perancangan menggunakan use case diagram untuk melihat gambaran pengelolaan data oleh admin terkait tampilan informasi yang disajikan pada website dan fungsi yang disajikan untuk pengguna [6]. Tidak hanya use case diagram yang digunakan sebagai komponen UML dalam suatu penelitian tetapi juga penggunaan class diagram seperti pada penelitian terkait perancangan arsitektur enterprise untuk meningkatkan kinerja layanan sistem informasi [7]. Diagram dari UML digunakan untuk membangun diagram UML yang lain karena adanya keterkaitan antardiagram [8].

\section{METODE}

\section{A. Jenis Penelitian}

Jenis penelitian yang dilakukan dalam penulisan ini berdasarkan fungsinya yaitu penelitian terapan (applied research), berdasarkan tujuannya yaitu penelitian dan pengembangan (research and development) serta penelitian deskriptif. Berdasarkan fungsinya, maka penelitian terapan (applied research) berkaitan penerapan dan pengembangan pengetahuan yang dihasilkan oleh penelitian dasar dalam kehidupan nyata yang mana bahwa penelitian dasar itu sendiri untuk menghasilkan pengetahuan dalam mencari solusi dari masalah-masalah umum, sedangkan penelitian terapan untuk mencari solusi yang berhubungan dengan permasalahan dalam suatu bidang tertentu. Dalam penelitian ini menggunakan pengembangan perancangan yaitu pemodelan UML untuk mencari solusi yang berhubungan dengan permasalahan dalam pengolahan data produk kerajinan.

Berdasarkan tujuannya yakni penelitian dan pengembangan (research and development) yang berfungsi untuk memperbaiki, meningkatkan, atau menghasilkan model yang sesuai standar. Dalam penelitian ini juga untuk mengetahui pengaruh sesuatu terhadap sesuatu lainnya yang dapat dilakukan dengan memanipulasi variabel tertentu untuk mempelajari pengaruh manipulasi tersebut terhadap variabel independen. Penelitian dan pengembangan bertujuan juga untuk menghasilkan produk tertentu dan menguji efektivitas produk tersebut. Produk dalam penelitian yang diteliti oleh penulis ini yaitu berupa perancangan yang dikembangkan dari perancangan awal menggunakan DFD dan ERD menjadi menggunakan UML.

Terkait analisis kebutuhan data saat ini, penelitian ini juga termasuk ke dalam penelitian deskriptif guna mendeskripsikan suatu keadaan atau fenomena apa adanya [9]. Penelitian deskriptif dapat dilakukan untuk saat ini atau dalam waktu yang singkat. Penelitian yang diteliti penulis terkait kebutuhan data saat ini yaitu sesuai dengan analisis kebutuhan saat ini pada produk kerajinan di showroom DEKRANASDA.

\section{B. Tempat Penelitian}

Tempat penelitian yang diperlukan pada penelitian ini yaitu pada showroom DEKRANASDA Provinsi 
Kalimantan Tengah yang berada di bawah naungan Dinas Perindustrian dan Perdagangan (DISPERINDAG) yang beralamatkan di Jalan Dr. Wahidin Sudirohusodo, Palangkaraya, Kalimantan Tengah.

\section{Teknik Pengumpulan Data}

Dalam pengumpulan data, penulis menggunakan beberapa teknik dalam membantu penulis untuk mendapatkan data yang tepat dan dapat diolah serta bermanfaat. Teknik pengumpulan data yang digunakan, yaitu:

1) Pengamatan (observation)

2) Wawancara (interview)

3) Kepustakaan (library)

Ketiga teknik pengumpulan data di atas telah dilakukan dan penulisan ini bersifat pengembangan, maka hanya memfokuskan pada bagian pemodelan.

\section{Prosedur Penelitian}

Pada penelitian ini, dilakukan beberapa tahapan penelitian yang dimulai dari identifikasi masalah hingga penyusunan laporan yang dilakukan seperti sebagai berikut:

\section{1) Identifikasi Masalah}

Analisis permasalahan untuk menentuan masalah terkait pengolahan data produk DEKRANASDA Provinsi Kalimantan Tengah dengan cara mengumpulkan data dan membaca literatur atau buku-buku, jurnal, dan artikel yang berkaitan dengan pengolahan data, perancangan, dan pemodelan menggunakan UML. Pengumpulan data juga dilakukan didapat dari hasil wawancara yaitu dengan cara mengajukan pertanyaan mengenai pengolahan data yang berhubungan dengan bahan penelitian, data produk, dan pertanyaan yang diajukan kepada pihak terkait pada showroom maupun kantor DEKRANASDA. Data yang terkumpul dari literatur maupun wawancara kemudian diolah menggunakan konsep pengembangan perancangan menggunakan pemodelan UML. Informasi yang diperlukan terkait pengolahan data produk yaitu data produk, data daerah, data pengrajin, dan data jenis produk. Data yang dianalisis dalam pengolahan data produk yaitu data produk, data daerah, data pengrajin, dan data jenis produk.

2) Rumusan Masalah

Penentukan variabel-variabel yang diperlukan dengan perancangan yang akan dikembangkan dan mendefinisikan masalah, tujuan, kebutuhan, serta solusi yang berpotensi dalam pengembangan perancangan pemodelan menggunakan UML yang berhubungan dengan pengelolaan data produk dan tool yang digunakan.

3) Perancangan Pemodelan

Perancangan pemodelan yang akan dikembangkan menggunakan komponen dari UML dengan hanya menggunakan beberapa diagram dari UML seperti use case diagram, sequence diagram, dan class diagram.

4) Analisis Data Hasil Pemodelan

Pada tahap ini dilakukan analisis perancangan untuk mengetahui hasil dari perancangan yang dilakukan. Menganalisis perancangan dengan menghubungkan pada pengolahan data dengan menerapkan konsep UML terkait produk kerajinan pada DEKRANASDA. Analisis data dari hasil pemodelan dilakukan untuk memastikan kinerja dan efektivitas dari semua komponen perancangan yang digunakan telah sesuai dengan alur perancangan.

5) Kesimpulan

Kesimpulan diperoleh dari hasil analisis penelitian yaitu berupa hasil analisis perancangan untuk mengetahui kinerja dari konsep UML yang digunakan terhadap perancangan yang dikembangkan mengenai data yang berhubungan dengan pengolahan data produk kerajinan pada DEKRANASDA.

6) Penyusunan Laporan

Penyusunan laporan terkait semua langkah-langkah dalam penelitian ini, mulai dari identifikasi masalah hingga memperoleh kesimpulan.

\section{E. Sistem Pengolahan Data Produk yang sedang Berjalan}

Sistem pengolahan data yang sedang berjalan saat ini hanya memiliki data berupa harga produk dan harga produk tersebut hanya ada pada beberapa produk saja. Sedangkan produk yang lainnya tidak memiliki data produk pada produk yang dipajang bahkan tidak memiliki data lengkap seperti nama produk, data jenis, data daerah, maupun data pengrajin. Produk yang disediakan pada showroom yaitu data yang hanya dipajang saja. Tidak ada stok barang pada produk yang berasal dari beberapa daerah. Sehingga jika kehabisan produk, maka stok produk benar-benar tidak ada. Produk yang ada pada showroom pun tidak memiliki pendataan seperti pada buku besar. Produk yang masuk pada showroom tidak dicatat sehingga tidak ada pendataan mengenai jumlah produk dan lain sebagai. Gambar 1(a) merupakan contoh produk yang dipajang tanpa data mengenai produk tersebut. Sedangkan Gambar 1(b) merupakan contoh produk dengan hanya pemberian keterangan berupa nama atau organisasi pengrajin. 
Keterbatasan data terhadap produk, tidak dapat mengenalkan para pengrajin produk sebagai penghasil. Hal ini juga akan membuat tersendatnya kreasi pengrajin untuk terus berkarya. Dengan adanya produk pada showroom, setidaknya dapat membantu memperkenalkan pengrajin agar pengrajin dapat terus mengembangkan produk yang dihasilkannya.

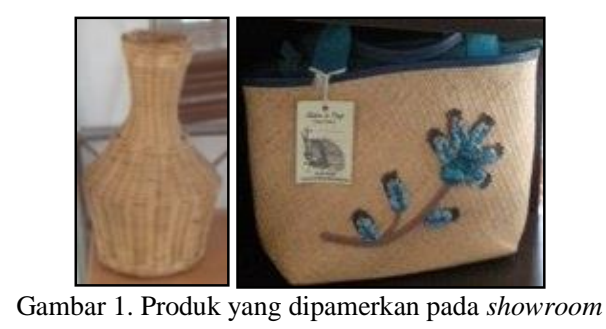

\section{F. Analisis Sistem Pengolahan Data Produk yang sedang Berjalan}

Dari hasil observasi dan wawancara dengan pihak DEKRANASDA dan penjaga showroom mengenai penyampaian informasi mengenai produk kerajinan, dapat disimpulkan bahwa pendistribusian informasi melalui cara-cara tersebut diatas belum tergolong sebagai penyampaian informasi yang efektif. Hal ini dapat dilihat dari:

1) Minimnya Data

Minimnya data pada produk yang dipamerkan di showroom, seperti data nama produk, asal daerah, harga jual, jenis produk dan keterangan lainnya yang dapat menonjolkan produk tersebut.

2) Tidak Adanya Pencatatan Data

Tidak adanya pencatatan data produk yang masuk pada showroom dan tidak adanya pencatatan produk secara lengkap pada buku besar maupun sejenisnya.

3) Pencatatan Manual

Jika ada barang yang dibeli maka hanya ada pencatatan manual untuk penjualan produk.

\section{G. Analisis Kebutuhan Sistem Informasi Pengolahan Data Produk}

Untuk menganalisis kebutuhan sistem informasi pengolahan data produk ini maka peneliti menggunakan konsep pemodelan UML untuk mengembangan perancangan dan menganalisis kebutuhan data serta kebutuhan proses. Sedangkan untuk pemodelan sistem menggunakan UML yang terdiri dari Use Case Diagram, Class Diagram, dan Sequence Diagram.

\section{H. Analisis Kebutuhan Data}

Beberapa data yang digunakan sebagai bahan untuk dianalisis terkait pengolahan data produk yaitu sebagai berikut:

1) Data Produk

Data produk mendiskripsikan data-data yang berhubungan dengan produk. Data ini juga memerlukan hubungan dengan data lainnya seperti data jenis produk dan data daerah.

2) Data Jenis Produk

Data jenis produk mendiskripsikan data-data yang berhubungan dengan jenis produk yang akan dihubungkan dengan data produk.

3) Data Daerah

Data daerah mendiskripsikan data-data yang berhubungan dengan daerah asal kerajinan. Data ini dihubungkan dengan data produk.

4) Data Pengrajin

Data pengrajin mendiskripsikan data-data yang berhubungan dengan pengrajin sebagai pembuat produk kerajinan.

5) Data Pengelola

Data pengelola mendiskripsikan data-data yang berhubungan dengan pengelola sistem atau admin. Data pengelola digunakan untuk masuk atau log in ke dalam sistem informasi pengolahan data produk.

\section{Analisis Kebutuhan Proses}

Proses diperlukan terkait pengolahan data menjadi informasi yang digunakan untuk dianalisis maka diperlukan beberapa alur terkait pengolahan data produk. Beberapa proses yang dilakukan pada sistem informasi pengolahan data produk yaitu sebagai berikut: 


\section{1) Input data}

Input data yang dilakukan yaitu data produk, data jenis produk, data daerah, data pengelola, dan data pengrajin.

2) Log in dan log out

Log in dan log out diberikan kepada pengelola sebagai hak akses pengelola terhadap sistem.

3) Ubah data

Ubah data yang dilakukan yaitu pengubahan untuk data produk, data jenis produk, ubah data daerah, dan ubah data pengrajin.

\section{III.HASIL}

Pengembangan pemodelan perangkat lunak dengan menggunakan UML dalam menganalisis dan memodelkan alur pengelolaan data produk pada showroom DEKRANASDA Palangkaraya berdasarkan pada pengumpulan data. Hasil penelitian ini ditujukan untuk mengetahui penggunaan pemodelan UML dalam memodelkan pengelolaan data produk.

\section{A. Rancangan Antarmuka Pengguna}

Antarmuka pengguna ditampilkan untuk layanan desktop yang terdiri dari form untuk hak akses yaitu untuk pengelola sebagai admin. Pada Gambar 2 menampilkan antarmuka menu utama. Pengelola akan disuguhi dengan tampilan menu utama sebelum login.

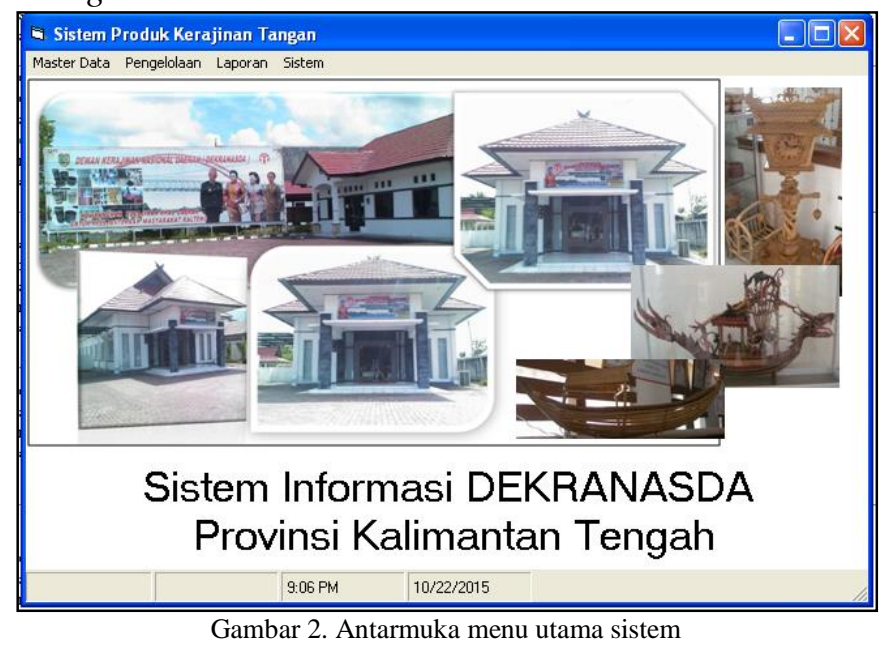

Untuk dapat masuk ke dalam hak akses pengelola yaitu dengan melakukan login terlebih dahulu melalui antarmuka login pengelola sebagai akses untuk dapat masuk ke dalam sistem dalam penyimpanan maupun manipulasi data. Akses login pengguna memerlukan data user name dan password pengguna. Menu login terdapat pada sub menu dari menu sistem.

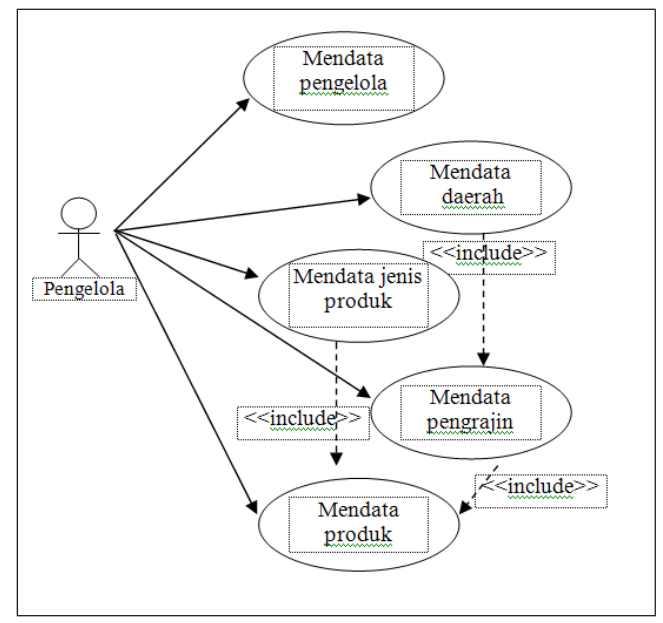

Gambar 3. Use case diagram

Pemodelan UML pada Sistem Informasi Pengolahan Data Produk DEKRANASDA Provinsi Kalimantan Tengah

Berdasarkan data yang telah diperoleh, maka dapat diidentifikasi hubungan antarkomponen yang diperlukan dalam pemodelan diagram. 


\section{B. Use Case Diagram}

Dalam membangun sebuah sistem, khususnya sistem informasi pengolahan data produk DEKRANASDA Provinsi Kalimantan Tengah dengan menggunakan pemodelan UML, maka salah satu langkah awal yaitu membuat perancangan konseptual untuk menjelaskan sistem yang akan dibangun atau dikembangkan. Salah satu nya yaitu dengan menggambarkan use case diagram sebagai rangkaian sistem yang saling terkait secara teratur yang dilakukan atau diawasi oleh sebuah aktor seperti pada Gambar 3.Berdasarkan Gambar 3, merupakan proses untuk memberikan gambaran yang terjadi. Pada use case diagram diketahui bahwa aktor yang terlibat pada proses tersebut adalah pengelola (petugas dari perwakilan provinsi di Kalimantan yang berwenang untuk mengelola data produk DEKRANASDA). Pengelola memiliki hak akses untuk masuk melalui login, dan melakukan pendataan untuk produk, pengelola, daerah, dan jenis produk.

Relasi include digunakan untuk menyatakan bahwa satu use case selalu menggunakan fungsionalitas yang disediakan use case lainnya. Tampak pada Gambar 3 bahwa use case "mendata pengrajin" memerlukan data daerah pengrajin yakni menggunakan relasi include untuk menghubungkan use case "mendata pengrajin" dengan use case "mendata daerah" karena use case "mendata pengrajin" akan selalu menggunakan fungsionalitas yang disediakan use case "mendata daerah".

\section{Sequence Diagram}

Pemodelan dengan menggambarkan sequence diagram untuk menampilkan interaksi-interaksi antar objek dalam sistem, termasuk pengguna, display, dan sebagainya berupa pesan atau penggambaran rangkaian langkahlangkah yang dilakukan sebagai sebuah respon dari suatu kejadian untuk menghasilkan output tertentu. Penggambaran sequence diagram dari sistem informasi pengelolaan data produk dapat dilihat seperti beberapa contoh pada Gambar 4, Gambar 5, dan Gambar 6.

\section{1) Sequence Diagram Mendata Pengelola}

Sequence diagram mendata pengelola seperti tampak pada Gambar 4. Pada Gambar 4, pengelola membuka halaman menu utama dari sistem yang digambarkan dengan simbol boundary yang merupakan interaksi antara aktor dengan sistem. Kemudian memilih menu login dengan mengisikan user name dan password, dalam hal ini menggunakan simbol control untuk menggambarkan koordinasi perilaku sistem, menangani tugas utama dan mengontrol alur kerja sistem serta dapat digunakan untuk menangani pengamanan. Begitu juga dengan menu manipulasi yang bertujuan untuk menangani kesalahan yang terkoneksi dengan database. Simbol selanjutnya menggunakan simbol entity untuk menu data pengelola dan data pengelola sebagai informasi yang terkait dengan sistem terutama penyimpanan seperti pada database.

\section{2) Sequence Diagram Mendata Jenis Produk}

Sequence diagram mendata jenis produk seperti tampak pada Gambar 5. Pada gambar 5, pengelola membuka halaman menu utama dari sistem yang digambarkan dengan simbol boundary yang merupakan interaksi antara aktor dengan sistem. Kemudian memilih menu login dengan mengisikan user name dan password, dalam hal ini menggunakan simbol control untuk menggambarkan koordinasi perilaku sistem, menangani tugas utama dan mengontrol alur kerja sistem serta dapat digunakan untuk menangani pengamanan. Begitu juga dengan menu manipulasi yang bertujuan untuk menangani kesalahan yang terkoneksi dengan database. Simbol selanjutnya menggunakan simbol entity untuk menu data jenis produk dan data jenis produk sebagai informasi yang terkait dengan sistem terutama penyimpanan seperti pada database.

3) Sequence Diagram Mendata Daerah

Sequence diagram mendata daerah seperti tampak pada Gambar 6. Pada Gambar 6, pengelola membuka halaman menu utama dari sistem yang digambarkan dengan simbol boundary yang merupakan interaksi antara aktor dengan sistem. Kemudian memilih menu login dengan mengisikan user name dan password, dalam hal ini menggunakan simbol control untuk menggambarkan koordinasi perilaku sistem, menangani tugas utama dan mengontrol alur kerja sistem serta dapat digunakan untuk menangani pengamanan. Begitu juga dengan menu manipulasi yang bertujuan untuk menangani kesalahan yang terkoneksi dengan database. Simbol selanjutnya menggunakan simbol entity untuk menu data daerah dan data daerah sebagai informasi yang terkait dengan sistem terutama penyimpanan seperti pada database.

\section{Class Diagram}

Class diagram terdiri dari beberapa tabel yang saling berhubungan dan digunakan dalam membangun sistem informasi terkait produk kerajinan tangan. Class diagram pada penelitian ini yaitu seperti pada Gambar 7. Pada Gambar 7 tampak diagram kelas / class diagram yang digunakan untuk menggambarkan semua kelas yang dapat digunakan dan hubungan relasinya. Beberapa kelas pada Gambar 7 saling terhubung dan ketergantungan karena antara satu kelas dengan kelas yang lainnya saling memerlukan. 


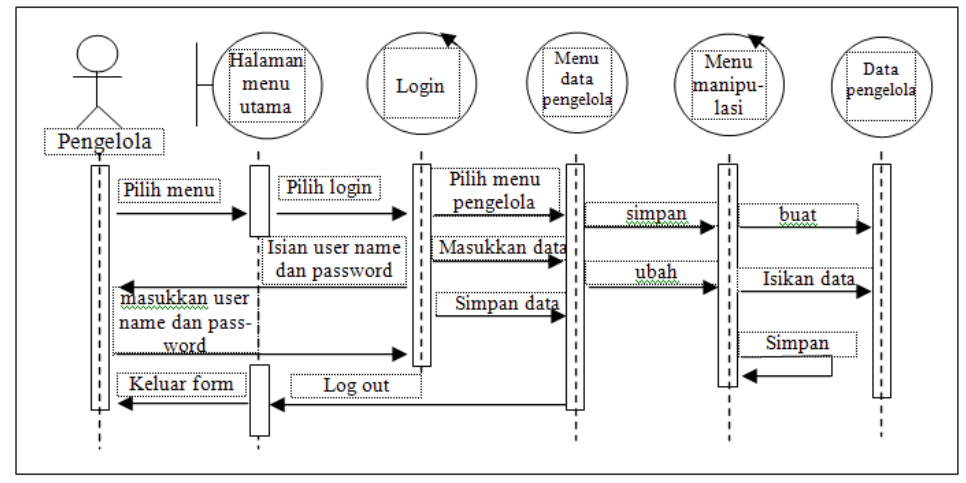

Gambar 4. Sequence diagram mendata pengelola

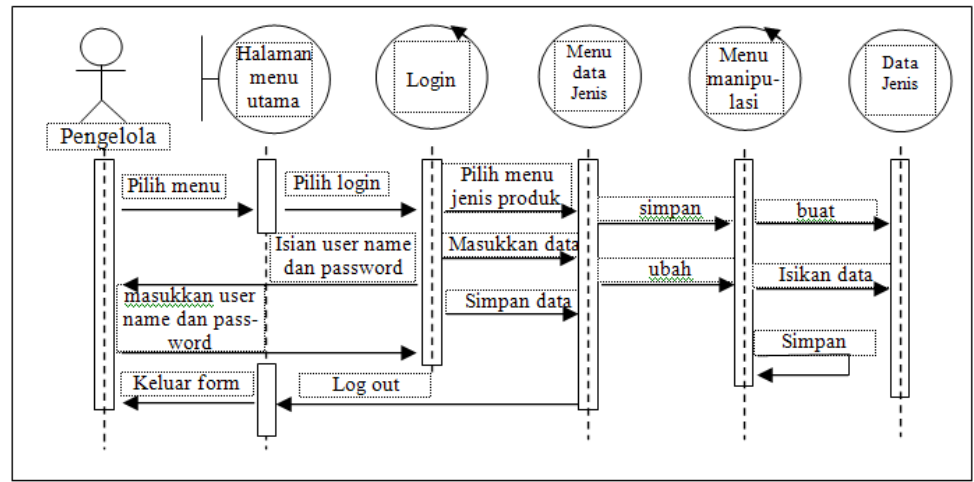

Gambar 5. Sequence diagram mendata jenis produk

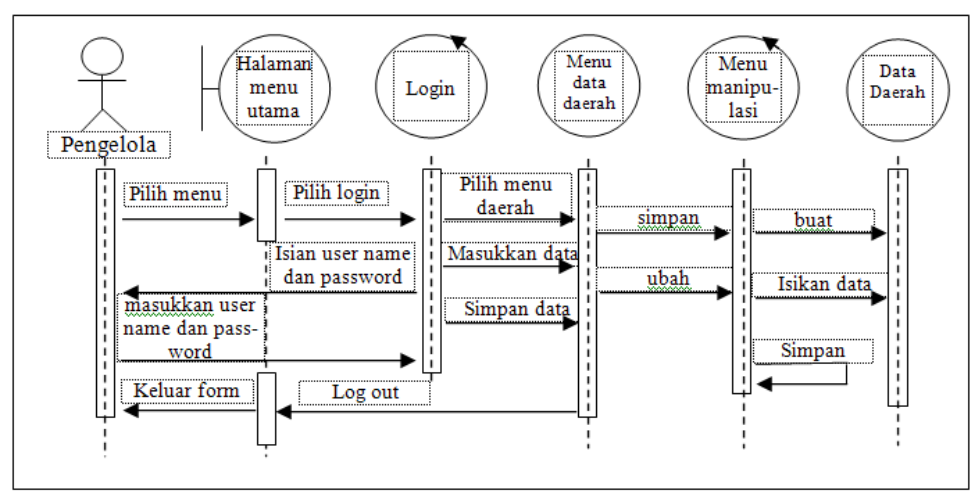

Gambar 6. Sequence diagram mendata daerah

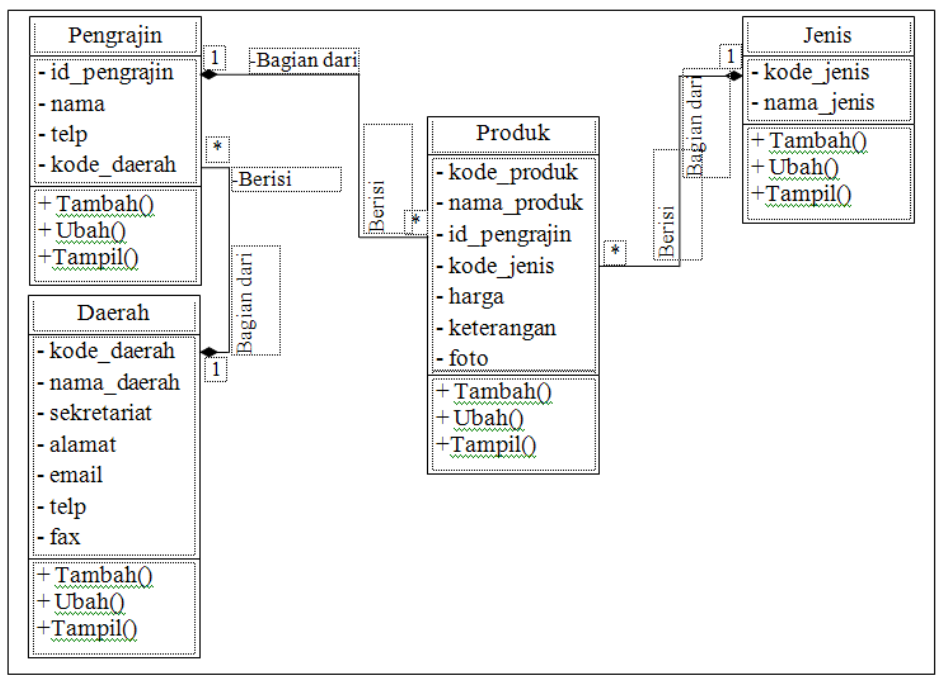

Gambar 7. Class diagram

IV. PEMBAHASAN

Pengembangan perancangan menggunakan pemodelan UML dengan melibatkan 3 diagram dalam UML yaitu Use Case Diagram, Sequence Diagram, dan Class Diagram dengan data input yaitu berupa data pengrajin, data 
produk, data jenis produk, data daerah, dan data pengelola aplikasi berdasarkan dari hasil analisis kebutuhan dalam perancangan sebagai data yang digunakan untuk mengembangkan pemodelan sistem. Pemodelan UML pada Sistem Informasi Pengolahan Data Produk DEKRANASDA Provinsi Kalimantan Tengah dengan menggunakan 3 diagram yaitu use case diagram, sequence diagram, dan class diagram.

Penggunaan use case diagram yang menggambarkan cara atau alur penggunaan sistem dari seseorang yang menjadi aktor yakni pengelola sebagai admin sistem pada penelitian ini. Pendekatan yang dilakukan pada use case yakni berfokus pada penggunaan yang diharapkan oleh pengguna dari sistem yang akan dibangun. Penggunaan sequence diagram untuk analisis dalam memperlihatkan cara aliran bisnis mengalir dalam suatu sistem. Penggunaan class diagram untuk memberikan gambaran sistem secara statis. Kelas-kelas yang ditampilkan berisi atribut dan operasi maupun relasi yang berkaitan dalam kelas-kelas tersebut seperti pada Gambar 7 yang memperlihatkan relasi atau hubungan antar kelas yang saling berkaitan dan saling berketergantungan. Class diagram merupakan salah satu alat perancangan yang dapat digunakan dalam pengembangan perangkat lunak agar pengembang bisa mendapatkan struktur sistem sebelum memulai untuk merancang dan menuliskan kode serta dapat membantu untuk memastikan pengembang bahwa sistem merupakan rancangan yang dirancang sebaik mungkin.

Adapun simpulan pada penelitian ini adalah:

\section{SIMPULAN DAN SARAN}

1) Pada penelitian ini dihasilkan sebuah pemodelan sistem informasi yang dapat mengolah data produk pada DEKRANASDA Provinsi Kalimantan Tengah dengan menggunakan pemodelan UML. Pemodelan yang dilakukan untuk membantu memecahkan permasalahan mengenai pengolahan data produk karena didapat adanya keterbatasan data produk berdasarkan dari analisis sistem yang berjalan sehingga diperlukan pengolahan data untuk mempermudah melakukan pengolahan data produk.

2) Prosedur penelitian yang dilakukan dimulai dengan melakukan identifikasi masalah sehingga diperoleh sebuah kesimpulan laporan yang menggunakan UML dalam perancangan pemodelan untuk dapat dilakukan analisis data dari hasil pemodelan. Pemodelan sistem menggunakan UML yang terdiri dari Use Case Diagram, Class Diagram, dan Sequence Diagram.

3) Pemodelan UML dengan menggunakan ketiga diagram tersebut merupakan salah satu alat perancangan yang dapat digunakan dalam pengembangan perangkat lunak agar pengembang bisa mendapatkan struktur sistem sebelum memulai untuk merancang dan menuliskan kode serta dapat membantu untuk memastikan pengembang bahwa sistem merupakan rancangan yang dirancang sebaik mungkin.

Pengembangan dapat dilakukan terhadap penulisan ini antara lain dalam saran sebagai berikut:

1) Dapat dilakukan implementasi sistem ke dalam aplikasi pemrograman dan basis data yang umum digunakan.

2) Pemodelan sistem ini dapat dikembangkan menjadi sistem yang dapat diakses secara lebih luas seperti online.

3) Pemodelan lainnya dapat dikembangkan dalam merancang sistem ini agar dapat diketahui perbandingan hasilnya.

\section{REFERENSI}

[1] I. Djon, Perancangan object oriented software dengan UML, Andi, Jakarta, 2005.

[2] L. Rusdiana, "Sistem informasi dekranasda provinsi kalimantan tengah menggunakan PHP 5 dan MySQL", STMIK Palangkaraya, Palangkaraya, 2010.

[3] V.D. Pavaloiaia and S. Catalin, "Experiments and results by modeling the financial domain with UML", Procedia Economic and Finance 20, 510-517, 2015.

[4] A.H. Khan and P. Ivan, "Consistency of UML Class, Object and Statechart Diagrams Using Ontology Reasoners", Journal of Visual Language and Computing 26, 42-65, 2015.

[5] Indrajani, Analisis dan perancangan sistem informasi card management, Prosiding KNSI 2009, 15-20, Informatika, Jogyakarta, 2009.

[6] Sarwosri and Nafisah, Perancangan dan pembuatan website e-gov studi kasus Kabupaten Pamekasan, Prosiding KNSI 2009, 3-8, Informatika, Jogyakarta, 2009.

[7] R. Lubis, Perancangan arsitektur enterprise untuk meningkatkan kinerja layanan sistem informasi, Prosiding KNSI 2009, 87-94, Informatika, Jogyakarta, 2009.

[8] K. E. Kendall and E.K. Julie, Systems Analysis and Disain, Prentice Hall, New Jersey, 2011.

[9] S. Guritno, Sudaryono, and R. Untung, Teori and Application of IT Research // Metodologi Penelitian Teknologi Informasi, Andi, Yogyakarta, 2011. 